possibilities of the resonance theory it seems easy by its use to account for the main facts of audition, none of which seem in conflict with the theory. This, of course, does not suffice to establish the hypothesis, as it is conceivable that some other might be equally successful. But, pending the advent of such a rival, perhaps the disciples of Helmboltz may be pardoned for what others might style their inexplicable interest in an old and unproved theory.

\title{
The Lesser Whitethroat's Fanfare.
}

(To J. S. H.)

\author{
THOUGH lyrics mingled with tattoos \\ Of melodrama savour, \\ The Lesser Whitethroat dares to use \\ Both avenues to favour. \\ Behind a screen \\ Of leaves unseen \\ He'll croon with tenderest passion, \\ Then loudly reel \\ A clarion peal \\ Of notes in fanfare fashion: \\ (Sotto voce, pp.) Chi'ddy-choo-ee'cheo,-Wee'jo-choo-ee'chey, \\ Wee'-chiddy-reee'chey,-Choo-itddy, Choo-ee' ! \\ Then changing time, \\ And reckless of rhyme :
}

\author{
(Vivace, Jf.) JIP-JIP-JIP-JIP, \\ JIP-JIP-JIP-JIP, \\ JIP-JIP!
}

But can we give this Warbler praise

When art he compromises,-

In secret hums his native lays,

And flash-notes advertises?

Sing, Warbler, sing !

These cries you fling

Too soon all tune will smother;

And then you'll flit

A ribald Tit,

And Whitethroats lose their brother!

W. Garstang.

\section{Obituary.}

W. H. Hudson.

$T H$ $\mathrm{HE}$ death of Mr. William Henry Hudson at his residence in London on August 18 , in his eightyfirst year, removes from our midst a remarkable personality, a great writer of English prose, and a keen interpreter of Nature.

Mr. Hudson's father emigrated to the Argentine in the early part of the last century and settled on the pampas, and it was there that his childhood and early life was spent. We get a vivid idea of the conditions under which he grew to manhood in the pages of "Far Away and Long Ago," a volume of autobiographical recollections which he published in $1918-$ the vast treeless plains, the solitary estancia with a few trees around it, the semi-savage gauchos, and above all the teeming bird life along the strand of a lonely mere.

In his early days Mr. Hudson entered into correspondence with the late Dr. P. L. Sclater and sent him collections of birds and mammals. Accounts of these, first appearing in the Proceedings of the Zoological Society, formed the foundation of a joint work, " Argentine Ornithology," published in two volumes in I888I889, to which Mr. Hudson contributed the notes and observations on the habits of the birds, while Dr. Sclater was responsible for the technical descriptions and general arrangement. This work was recently reissued by Mr. Hudson alone, but without the technical descriptions, under the title of "Birds of La Plata." Two other volumes, well known to lovers of good writing dealing with South American Natural History, were "The Naturalist in La Plata," I892, and "Idle Days in Patagonia," I893. About this time Mr. Hudson came to England and limpid, lucid, English prose. began a long series of works dealing with the study of Nature in England. "Birds of a Village," " Nature in Downland," "Hampshire Days," "The Land's End," and the more strictly ornithological "British Birds," "Birds and Man," and "Birds in London," followed one another in quick succession. Though always in feeble health and of a delicate constitution, he tramped over southern England from the New Forest to Penzance throughout the summer, spending the winter partly in London and partly at Penzance, where he made his second home.

Recognition of his talent came late to him. In his early days in England he was unable to earn a livelihood with his pen and he was awarded in rgor a Civil List Pension of $\mathbf{I} 5 \mathrm{Ol}$. in " recognition of the originality of his writings on natural history." This he resigned in August last year on the ground that he needed it no longer. "Publishers," he told an intimate friend, "threw money at him with both hands."

A man of extremely sensitive temperament, Hudson could not endure to take the life of any animal or bird, and was an ardent supporter of the Society for the Protection of Birds, to which he devoted much of his energy during recent years. He was thus out of sympathy with any form of collecting. He had, however, a wonderful powèr of observation, and his sense of hearing was extremely acute. His writing is simple, lucid, and descriptive, and he never gave to his observations on bird or animal psychology that anthropomorphic tendency which so often characterises the writers of popular works on natural history subjects. Though he can never be reckoned among the ranks of scientific ornithologists, his writings will undoubtedly endure as monuments of accurate observation and of 